Board of Governors of the Federal Reserve System

International Finance Discussion Papers

Number 657

January 2000

'HERE, DOLLARS, DOLLARS...' - ESTIMATING CURRENCY DEMAND AND WORLDWIDE CURRENCY SUBSTITUTION

Brian M. Doyle

NOTE: International Finance Discussion Papers are preliminary materials circulated to stimulate discussion and criticial comment. References to International Finance Discussion Papers (Other than an acknowledgement that the writer has had access to unpublished material) should be cleared with the author or authors. Recent IFDPs are available on the Web at www.bog.frb.fed.us. 


\title{
'Here, Dollars, Dollars...' - Estimating Currency Demand and Worldwide Currency Substitution
}

\author{
Brian M. Doyle* \\ Board of Governors of the Federal Reserve System
}

January 2000

\begin{abstract}
In measuring the percentage of foreign-held U.S., German, and Swiss currencies for the period of the 1960s through the 1990s, I obtain estimates much different from those of others. Using currency demand equations implied by cointegrating vectors for Canada, the Netherlands, and Austria, I estimate that in 1996 only 30\% of U.S. currency was held outside the United States, and as much as $69 \%$ of German currency was held outside Germany. The U.S. estimate falls slowly over the 1960s, reaching a low of $5 \%$ in the first half of the 1970s, then rises through the early 1980s and again during the 1990s. Given that foreign holdings of the U.S., German, and Swiss currencies constitute the bulk of international currency substitution in the world, I find that, adjusted for inflation, currency substitution roughly tripled from 1986 to 1996.

Key Words: Currency Substitution; Currency Demand; Money Demand; International Use of the Dollar; Underground Economy

JEL Classification: E41; F41; K42
\end{abstract}

\footnotetext{
*Mailstop 24, Federal Reserve Board, Washington, DC 20551, (202) 785 6011; brian.m.doyle@frb.gov. All errors are, of course, my own. I would like to thank Ruth Judson, Maria Goodwin (U.S. Treasury), Susan Perrault (Bank of Canada), H. Wolff (Bundesbank), G. Hebbink (Nederlandsche Bank), and M. Senn and M. Feller (Swiss National Bank) for help in obtaining data. I also thank Jean Boivin, David Bowman, Steve Kamin, Doug Miller, Don Redl, Ernst Schaumburg, Franz Seitz, Jonathan Wright and especially Peter Kenen, Ken Rogoff and Mark Watson for helpful comments and discussions. Thanks to Princeton's International Finance Section for financial support. The views in this paper are solely the responsibility of the author and should not be interpreted as reflecting the views of the Board of Governors of the Federal Reserve System or of any other person associated with the Federal Reserve System.
} 


\section{Introduction}

Approximately 382 billion dollars (U.S.) of currency was in circulation in 1995, which is about $\$ 1,452$ per person (see Table 1 ). About sixty per cent of the U.S. currency's value is in one hundred dollar bills. Per person then, Americans carry almost nine one hundred dollar bills each. This is not solely an American phenomena, however, with Germany, Japan, and Switzerland having per capita currency outstanding of about $\$ 2,000, \$ 4,000$ and $\$ 4,000$ respectively. Germany has about thirty percent of its currency in 1000 DM bills (about 625 U.S.\$). At the same time, surveys of households' and businesses' currency holdings in the US suggest that only about eight and a half percent of all cash is in their hands (see Table 2$)^{1}$. Where is the rest? I estimate how many U.S. dollars, German deutschemarks and Swiss francs are held by people outside of those countries from 1960 to $1996^{2}$. In other words, assuming that these currencies make up a substantial portion of the currency held outside the borders of the issuing nation, I estimate the extent of worldwide currency substitution.

I arrive at results which differ markedly from current popular estimates of U.S. currency held abroad, which are in the 50-70\% range. Instead, my 1996 estimate for the United States is 30\%. For both Germany and Switzerland the percentages are even higher at $69 \%$ and $77 \%$. Probably the single most compelling reason to believe the U.S. estimate, in particular, over others is that it implies a level of per capita domestic currency that is in the same range as other Western nations of its size, etc.. The international use of the dollar has varied considerably over time. It started at roughly $15 \%$ in the early 1960 s and fell to $5 \%$ in the early to mid 1970 s. It started to rise during the late $70 \mathrm{~s}$ and early $80 \mathrm{~s}$ and increased dramatically over the rest of the period. My estimate for Germany stays relatively constant for much of the period, then as well increases dramatically at the end of the sample. Only the percentage of foreigners holding Swiss currency, with still the highest 1996 estimate, has had a decline. Overall these estimates yield a world currency substitution of roughly 240 billion 1990 U.S. dollars in 1996. The results seem to indicate that currency substitution (in the form of just cash) is much more important in the 1990s than it was in the 1970s or 1980s. In fact, it has approximately tripled over the past decade

\footnotetext{
${ }^{1}$ Sprenkle (1993) outlines the case of there being more currency than is reasonable for domestic, legal transactions. Table 1 is an updated and expanded version of Sprenkle's own table listing currency per capita for numerous countries around the world. Table 2 is currency surveys done by Avery et al. (1984, 1987) and Porter and Judson (1996) for the United States. Cramer and Reekers (1976) has a survey of the Netherlands. Other interesting papers include Feige (1994) and Anderson (1977) who points out that very little cash is ever lost.

${ }^{2}$ We exclude Japan for lack of a satisfying 'proxy country', the need of which becomes apparent later on.
} 
in constant dollar terms.

My estimates for currency substitution are derived using estimated currency demand functions of three other nations, Canada, the Netherlands and Austria. These currency demand functions are interesting in their own right. Regressions with ln total real currency per capita as the left-hand side variable, for the most part, have the expected signs on retail sales and interest rates. I get different results when I split currency into large and small value denominations. The signs and significance of the coefficients are unchanged with just large denomination bills. When just small denomination bills are used, those same coefficients tend to be insignificant or to have point estimates with the opposite signs. These smaller bills are the ones that I expect those operating in the legitimate economy to be more likely to use, and so this result may indicate an invalidation of traditional explanations of currency demand or simply a movement away from small to large bills (in real terms), or cash to other instruments as incomes have risen. I also find, as Ball (1998) for post-war M1 demand functions, some evidence that the currency demand functions are stable over the period 1960-1996.

This paper builds on the work of Sumner (1990), Porter and Judson (1996), and Seitz (1995), but is different in several key ways. First, I use more 'standard' currency demand functions instead of other currency characteristics to estimate foreign holdings ${ }^{3}$. Porter and Judson, as well as Seitz, use characteristics such as seasonality, the ratio of notes to coins, and other ingenious methods to arrive at their estimates. My currency demand functions also allow me to attach some measure of uncertainty to my estimates which I arrive at using more modern cointegrating techniques (see Stock and Watson (1993)). I am also able, as reported above, to plot how the percentage of currency changes over time, instead of an average over a certain time period. Finally my coverage of nations is slightly broader including the United States, Germany and Switzerland as opposed to focusing on one of these nations. The paper also builds on the work of Stock and Watson and Ball, in estimating currency, as opposed to money, functions.

One might ask, why do we care? The size of these currency stocks is a measure of the total seignorage and amount of the "interest-free loan" to the central bank by the holders. With several currencies in the world being used by foreigners, there is the possibility of people switching from one to the other (see Rogoff (1998)). This paper would then, for example, help to answer what the cost to the United States would be if some portion of foreigners who currently hold greenbacks switch to the new euros which have higher denominations. Also the holdings of currency are related to the size of the American underground economy. For the countries that I am

\footnotetext{
${ }^{3}$ Seitz (1995) does study the currency demand of Germany using a VECM approach and also used the forecast errors to try to estimate German currency abroad.
} 
talking about here, estimating the size of the foreign-held currency stock is a first step to getting better estimates of the domestic underground economy. Finally, if we believe that these currencies comprise most of the foreign holdings of currency in the world then together they provide a measure of world currency substitution (for an excellent survey of the literature see Giovannini and Turtelboom (1994)). Currency substitution studies have focused primarily on individual countries (see Savastano (1996) for example). There are fairly large difficulties in trying to estimate currency substitution, most importantly that at the very time that you are interested in currency substitution is usually also the time when data is most suspect (i.e. during a crisis). Estimating currency substitution "from the other side" might help in getting a more accurate idea of the phenomenon.

\section{How will I estimate it?}

So what is it that I am going to do? I want to outline a method by which I will estimate the international use of United States currency (amongst others), namely by estimating currency demand functions, and then talk about how I will estimate those currency demand functions, namely by cointegrating vectors.

\subsection{Estimating Foreign Holdings}

How do I estimate the portion of the currency stock that foreigners hold? ${ }^{4}$ There is an aggregate stock of currency holdings, $M_{t}$, that I wish to identify as having two parts. A domestic portion, $M_{t}^{D}$, which is held by households and businesses not only for legal transactions, but as well for illegal transactions and hoardings (from crime, tax evasion, etc., as well as legitimate motives). As well, there is a foreign component, $M_{t}^{F}$, which is, as its name suggests, the holdings of the domestic currency by foreigners. The only component that we observe is the total, and so I need some assumptions to identify one of the others. My assumption, which has its origins in Sumner (1990) and Porter and Judson (1996) is that I can proxy the domestic portion of the United States' real per capita currency stock with the currency demand

\footnotetext{
${ }^{4}$ There are two ways to measure the portion of the currency stock which is held by foreigners. Either we could find data, that explains the size of foreign holdings directly or we can try to find characteristics that explain domestic holdings and then take foreign holdings as the residual, what Feige (1996) calls the "indirect method". Both methods have their problems. A lack of data plagues the first method. Though there exists reports detailing movements of currency through banks of amounts greater than $\$ 10000$, there is no record of the potentially countless "briefcases full of cash" that travel across the border, or the multiple transfers of just under 10000 to avoid reporting requirements. For one example of such a method see Kamin and Ericsson (1993). For the second, whatever characteristics we use to try to estimate domestic holdings may also not be perfect.
} 
function using total real per capita currency stock for Canada ${ }^{5}$ (and for Germany and Switzerland I use the Netherlands and Austria respectively). In other words, I can estimate a currency demand function for Canada and that same relationship will hold for the United States' domestically held cash. Imbedded in this assumption is that no Canadian currency is held abroad and that I can ignore any other nation's currency (particularly the U.S. dollar) held by Canadians. I also am saying that I believe that the parameters describing tastes, preferences, and technology are the same (or very close to being so) in the two economies. This similarity leads to the same relationship between real per capita retail sales and interest rates and the amount of real per capita currency that are held domestically. This further says that things that we do not measure such as taxation and crime rates, illegal activities that may drive currency holdings, have similar effects in aggregate.

With this assumption I can estimate foreign holdings in the following way. I first estimate a currency demand function for Canada roughly of the form:

$$
\begin{aligned}
(\text { Real per capita Currency Balances })_{\text {Canada }}= & \beta_{0}+\beta_{1}(\text { Real per capita Retail Sales })_{\text {Canada }} \\
& \left.+\beta_{2} \text { (Nominal Interest Rate }\right)_{\text {Canada }}+\text { etc... }+e_{t}
\end{aligned}
$$

where all variables except the interest rate are in natural logarithms, and the 'etc' merely indicates additional terms, such as leads and lags, depending on the cointegration method used (see below). With the estimates (indicated with carats) of $\beta_{0}$, $\beta_{1}$, and $\beta_{2}$, I can take American data and compute the amount of real American currency per capita that Americans hold like so:

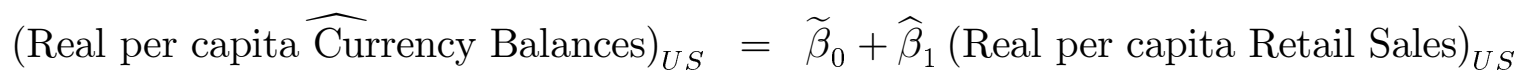

$$
\begin{aligned}
& +\widehat{\beta}_{2}(\text { Nominal Interest Rate })_{U S}+\widehat{e t c} \ldots+e_{t}
\end{aligned}
$$

where $\widetilde{\beta}_{0}=\widehat{\beta}_{0}+\left(1-\widehat{\beta}_{1}\right) \cdot$ Exchange rate 1990 so that I correct for the fact that the 1990 dollars of the two countries are in two different currencies ${ }^{6}$. Then to get the

\footnotetext{
${ }^{5}$ A similar exercise was conducted for the United States and Germany by Porter and Judson (1996) and Seitz (1995) respectively. In both these cases, the authors estimated money demand functions within country at an earlier date and then identified residuals of those functions as being explained by foreign holdings. Both authors also tried a variety of other characteristics of the pairs of countries to try to identify domestic cash. These included such things as the notes to coins ratios and the seasonality of the currency. Details of these methods can be found in Porter and Judson (1996). Feige (1996) using more 'direct methods' comes up with numbers more on the $40 \%$ range.

${ }^{6}$ We have done all of our calculations in each countries own currency and deflated by the price level to get real variables. Since the price indices are normalized so that 1990 is equal to 100, we
} 
percentage of foreign holdings I extract my computed domestic holdings from the total (after turning the log values back into levels).

$$
\begin{aligned}
& \text { Percentage of US Currency Stock held abroad } \\
= & \frac{(\text { Real per capita Currency Balances })_{U S}-\left(\text { Real per capita } \widehat{\text { Currency Balances })_{U S}}\right.}{\text { (Real per capita Currency Balances })_{U S}}
\end{aligned}
$$

To get the total amount of foreign holdings we must multiply by the total amount of the currency stock.

That the countries are good matches is not something that I "prove" here in this paper, indeed it is something that would be hard to do. What I need to do is compare the domestic holdings in the two countries to their economic characteristics, but the domestic holdings are exactly what I am trying to identify for one of the nations. I make two weak appeals though that the matches make sense. First, culturally and economically they are certainly very similar nations although the first two pairs are, of course, very different in size. Second, while we cannot observe how cash holdings are used there is some limited data which the Bank for International Settlements collects for non-cash transactions. With this I can compare at least the first two of my matches - Canada-U.S. and Netherlands-Germany. In table 3, we can see that each of these pairs over the 1983-1995 period (there is more frequent data near the end of the sample, but the numbers here give the essential picture.) has a similar proportion of its noncash transactions in each of the categories of credit cards, cheques, credit transactions and direct debits, with some exceptions. Cheques and credit cards are quite popular in Canada and the United States. Credit transactions and direct debits are more popular in the Netherlands, Germany and Switzerland. These numbers are not just a North American-European split. The Netherlands and Germany are closer to one another than they are to others within Europe. There are also some differences. The Netherlands and Germany seem to be diverging on credit cards by the end of the sample, as are Canada and the United States on cheques versus credit cards. Both of these pieces of evidence in no way prove my assumption, but they are suggestive of it being a reasonable one with varying degrees of confidence. While I believe the Canada-U.S. matching to be relatively solid, I am less confident in the NetherlandsGermany pairing and even less confident in the Austria-Switzerland couple. All of the results later in this paper, should be viewed with this in mind.

still need to correct for the exchange rate in that year. We do our transformations in this way, i.e. rather than just converting all series to the other currency, so that we do not pick up exchange rate variations in our estimate of foriegn holdings. 


\subsection{Estimating Currency Demand}

How am I going to estimate currency demand? The estimation method that I will follow is to estimate the cointegrating relationship between real currency balances, interest rates and retail sales ${ }^{7}$. As with the money demand literature I find that most of the data is characterised by unit roots and all regressions yield strong positive results in both residual based and Johansen cointegrating tests ${ }^{8}$. The exception is real currency per capita in Austria, the interest rate in the Netherlands and retail sales for most of the countries. It is usually the case that GDP is used instead of retail sales in the money demand literature. I use retail sales because of its availability monthly and because I believe that retail sales is a more pertinent transaction variable for currency as opposed to M1. Because of the strong cointegration test results I proceed with that form of estimation.

Many ways have been developed to estimate cointegrated relationships, and in this paper I will estimate the set that are compared in Stock and Watson's (1993) Econometrica article. It is worthwhile to estimate each of the relationships for a few reasons. Stock and Watson do Monte Carlo test of each of these estimators and find that each of the estimators has some drawbacks - substantial bias and lower efficiency depending on the relationship estimated. It also seems appropriate to follow Stock and Watson as they actually apply these estimators in their article to M1 demand (and find that there is some instability in post-war money demand). So I will estimate the following eight specifications: (1) ordinary least squares or what Stock and Watson call static OLS (SOLS), (2) non-linear least squares (NLLS), (3) dynamic ordinary least squares (DOLS), (4) dynamic generalised least squares (DGLS), (5) Phillips' (1991) spectral estimator (PBSR), (6) Phillips and Hansen's (1990) and Park's (1992) two-step zero-frequency estimator (PHFM), (7) Johansen's estimator with 2 lags $(\mathrm{JOH}(2))$, and (8) Johansen's with three lags $(\mathrm{JOH}(3))$. The details of each of these procedures can be found in Stock and Watson.

That said, I will focus on the DOLS estimator. DOLS is one of the two estimators that Stock and Watson propose themselves (DGLS is the other) as being a simple efficient estimator of cointegrating relationships. It has a low bias relative to the other procedures, except for $\mathrm{JOH}$ which is unbiased, but has a greater dispersion than the other estimates. The DOLS procedure that I estimate has three versions each of which correct for serial correlation. The first, which is also the one that will be reported in my tables and graphs, uses a Bartlett kernel to average the first 5 error autovariances. The other two both use an autoregressive spectral estimator, one with 2 and the other with 12 lags. In each case, this implies that I will estimate

\footnotetext{
${ }^{7}$ See Goldfeld (1990) for a survey on the older literature on estimating money/currency demand functions.

${ }^{8}$ Further details of which are available by request.
} 
the following specific equation for the proxy country:

$$
\begin{aligned}
(\text { Real Currency Balances })= & \left.\left.\beta_{0}+\beta_{1} \text { (Retail Sales }\right)+\beta_{2} \text { (Interest Rate }\right) \\
& +d_{R S}(L)(\text { Retail Sales })+d_{I}(L)(\text { Interest Rate })+e_{t}
\end{aligned}
$$

where L indicates lead and lagged variables, of which I include two of each. After this estimation, as I outlined above, I will take the coefficients and with data from the other member of the pair, compute what the currency stock would be if no foreigners held any of its currency. I also compute some stability tests for each nation. For this I follow the procedure of Bruce Hansen (1992) which is a test for stability when the break point is unknown. I will also calculate a Wald stability test of the DOLS equations and confidence ellipses at the midpoint of my sample. I do the Wald test as it has more power than Hansen's test.

There are a few caveats to my estimation. The assumption is that central banks will simply accommodate any currency demand that agents wish and then counteract its effects on the broader aggregates of money and interest rates. In this way the level of currency does not affect broader economic activity. This assumption is maintained so that I do not have this particular identification issue in this single equation estimation. Also, as transactions technology and costs change over time then the proportion of currency that needs to be held by households and businesses should change. Likewise one might believe that criminals and tax evaders have made use of these technologies to better launder money and hence make less use of cash. I am regretfully ignoring any differences in these effects across nations. Incorporating measures of these effects into my regressions would be a positive development, but one unfortunately that I will leave to future research.

\section{Data}

A brief excursion to say a few words about the data used. I have monthly data on the holdings of currency, consumer prices, retail sales, population and short term interest rates from 1960 to 1996. The data on currency balances, interest rates, population, and consumer price level came from the International Financial Statistics (IFS) of the International Monetary Fund (IMF). The series on retail sales came from the Organisation for Economic Cooperation and Development (OECD). For the Netherlands, Austria, Germany and Switzerland the retail sales data was in the form of an index with 100 equal to 1990. Canada and the United States were already in levels. The level of retail sales for Austria, the Netherlands, Germany and Switzerland came from Euromonitor's European Marketing Data and Statistics ${ }^{9}$. These were

\footnotetext{
${ }^{9}$ Note that it is possible that there are slight indescrepancies in the two series.
} 
combined with the OECD's index of retail sales using the value for the total level in 1990 mapped to the relative weights of the index in $1990^{10}$. Currency by denomination was provided either by the respective central banks or obtained from the annual reports or statistical reports of the central banks. For Germany, Austria and the United States' denomination data there were some data points that were unavailable. In the case of Austria, these were the first ten data points of the sample. Regressions run for Austria on currency broken down by denomination, thus start a few periods later than the Netherlands and Canada. The interest rate in the case of Canada and the U.S. was the discount rate and the federal funds rates respectively. In the case of Germany and the Netherlands the rate was the commercial paper rate and in Austria and Switzerland the rate was the discount rate. The rates were chosen in part for their availability at monthly intervals for the 1960-1996 period. Population was available on a monthly basis for only the United States. For the other countries, the yearly population was fitted to a polynomial using the annual level as the level in January. Both the currency and retail sales data is expressed in real per capita terms. All of the data is in logs and in its own national currency.

\section{What do I find and what does it mean?}

In short, I find that the currency demand functions have coefficients with signs that you would expect them to have. In most cases, retail sales is positive and interest rates are negative with both being significant. When I split the currency data into large and small denomination notes, the signs flip for the small ones. Finally, there seems to be some evidence that the equations are stable over the period 1960-1996.

\subsection{Regressions}

As we can see in table 4, the coefficients on my regressions, for the most part, have the 'right' signs and are significant. The one exception is the Netherlands which in several of the estimations has a positive sign on interest rates and a negative sign on retail sales. The estimated coefficients vary somewhat over the different procedures. Here my estimates are reasonably close for DOLS, PBSR and PHFM, and occasionally the magnitudes of the others are close. I calculate the $95 \%$ confidence intervals for each nation in figure 1 and see that for most procedures the estimates are clustered

\footnotetext{
${ }^{10}$ In other words the total level for 1990 can be portioned up so that we can find the monthly values. If we had monthly levels instead of an index, the yearly level should be equivalent to the sum of the monthly values. So we can take the yearly level total and divide by the monthly index sum. Then we multiply that number by the individual monthly index weights we get the monthly levels. With a monthly level and the index we can compute the rest of the index.
} 
together. The magnitudes of the coefficients for Canada and Austria seem potentially high, but within the realm of reason. A simple form of the quantity theory would imply an income coefficient of one and the Baumol-Tobin framework would indicate a coefficient of 0.5 . Here the values are generally less than one for retail sales, i.e. a one percent rise in retail sales yields a less than one percent rise in the demand for currency. I also run these regressions on the United States, Germany and Switzerland. If we believe that significant proportions of the currency stock is held outside of these nations then these regressions with total currency stock in them are somewhat suspect, in the sense that we do not have all of the explanatory variables. Still it is illustrative that the size of the coefficients are generally (but certainly not universally) bigger when compared to each of the corresponding proxy nations, particularly the coefficient on retail sales, and the constant term which is not reported in the tables. When the data for these nations is applied to the proxy countries coefficients they will indeed give domestic currency balances that are less than the total stock outstanding. Note further that the values of the coefficients for retail sales are generally higher than one, but not excessively so.

\subsubsection{Big versus Small Bills}

I can also run my results on subsets of the currency stock by denomination. For example it would be interesting to see if large versus small denominations give different results. I divided the currency base in a somewhat arbitrary manner. Since relative to the U.S. dollar some bills might start off large and then end up small, I picked 1990 as the year to make the cut-off regardless as to what movements the exchange rate made before or after that date. I then picked 37.50 American as the dividing line, which intentionally makes the $\$ 50$ bill in Canada a large bill.

The results in fact are rather surprising. As we can see in tables 5 and 6 , I have the collection of cointegration approaches by small and large bills. The large denomination regressions have the same signs and much large magnitudes than the 'pooled' regressions, and are highly significant. This situation is not the case for small denomination notes. In most cases for the small bills the coefficients on retail sales and interest rates are also significant in all of the countries. That said, it is also the case that the coefficients are of the opposite sign- negative rather than the expected positive coefficient on retail sales, and positive rather than negative on interest rates. There are three possible interpretations of the results. If you interpret these coefficients as simply not being significant at all, then it may be that the traditional model for currency balances (such as Baumol-Tobin, or a Quantity Equation) simply does not hold. Perhaps it is the case that households follow rules of thumb that do not correlate at all with interest rates or retail sales. For example, consumers could have a set amount of purchases that they make with cash and hold 
just enough to cover these. All other purchases they make with other instruments, such as credit cards or direct debits. Another explanation tries to make sense of the negative sign on retail sales. Let us assume that small denominations are used for only legal purposes. The regression would then make sense if people were switching from cash to cashless transactions, as we might expect over this period. As retail sales have gone up over time the use of cash has not, in real terms. The third explanation is also reasonably plausible. As people receive more real income that switch from small denominations to larger denominations. I have tried to split the denominations such that I have avoided this problem though where the large bills are ones that we suspect are not often used in the legal economy.

\subsubsection{Stability}

There is mixed, but somewhat favourable evidence of the estimates' stability over the period from 1960-1996. I provide several pieces of evidence for this conclusion. my first piece of evidence is in figure 1, where I graph the F statistics from Hansen (1992) test for parameter instability in cointegrating relationships. The test is on all parameters in the regression. In all three countries the $\mathrm{F}$ statistics are well below the $5 \%$ significance line for the supF critical value. Only in the case of Austria do the F statistics briefly cross the $5 \%$ line for the MeanF test. Even here the F statistics that are higher are at the ends of the sample. The power of this test is low however, so I also calculate Wald statistics on a structural break in the DOLS estimation of currency demand at the midpoint in the sample. In the version that is presented in my tables, which corrects for serial correlation using a Bartlett kernel, all of these Wald tests for each country show instability. When I use a spectral estimator for the same task at 2 and at 12 lags the results are quite different. All of the Wald tests show stability at the $5 \%$ level for all countries with 2 lags. When the sample is split between large and small denomination bills the Wald tests show instability for the Netherlands for large bills, and both Austria and the Netherlands for small bills at 2 lags. All Wald tests for 12 lags show no instability at the $5 \%$ level. Still as a further exercise I present $95 \%$ confidence ellipses for four of the methods for each country in Figures 2 through $5^{11}$. The two ellipses are for the first and second halves of the sample. I find that these ellipses overlap or nearly overlap for DOLS, DGLS, PBSR, PHFM near its full period estimated parameter values in the cases of the Netherlands and Austria ${ }^{12}$. In the end though, even if the equations did have structural breaks in

\footnotetext{
${ }^{11}$ Stock and Watson point out that the confidence ellipses may not match the asymptotic intervals, and perform Monte Carlo experiments to demonstrate this. They show that as the sample size increases this problem diminishes. With 444 observations our ellipses should be fine.

${ }^{12}$ Again if the serial correlation correction is the spectral estimator with 2 lags, then the confidence ellipses overlap for Canada as well, though do not for PBSR and PHFM for all of the countries.
} 
them, that would not invalidate this method, though it could be quite inefficient (i.e. I could estimate an equation with the breaks). If there were a structural break with the oil shock, for example, I could estimate an equation with a structural break and then use that equation to compute the domestic holdings.

\subsection{Foreign Holdings and Currency Substitution}

\subsubsection{Foreign Holdings}

Figure 6 and 7 present my calculations of foreign holdings as percentages of the currency stocks in the United States, Germany and Switzerland ${ }^{13}$. The United States had about thirty percent of its currency abroad in 1996 in this approach. This figure changed considerably over time. It was falling slowly over the nineteen sixties and was as low as five percent in the early to mid 1970s. It then shot up in the late 1970s and early 1980s and then started to rise again in the early 1990s. Given the world events and other studies on currency substitution in Latin America, these figure seem to make sense on a stylised level. Particularly if one believes, as many do, that the destination of currency was Latin America in the mid 1970s to mid 1980s, and Eastern Europe and Russia in the 1990s for both the United States and Germany. During the 1970s and early 80s and again after the fall of the Iron Curtain there were large surges in the percentages of dollars outside the U.S. and of marks outside for Germany. In Switzerland there seems to be a fall since about 1980, which might reflect it losing its appeal as a haven for storing funds. It also might reflect some switching from the Swiss franc to the deutschemark, which would also help to explain the increases in German foreign holdings at the same time. Still the percentage for Switzerland is extremely high, and the overall movement in terms of percentage points is relatively small, so the estimate may simply reflect a poor choice of country pair (Austria).

A few further points about my estimates. Unlike previous estimates of the currency held abroad, I am able here to assign some measure of uncertainty. This measure, of course, cannot include my assumptions across countries, but given those assumptions I can compute standard errors from the currency demand functions. Figure 7 is my calculation of foreign holdings with 2 two standard error bands on either side. Since I have variances for my estimated parameters and all of the equations that I estimate are linear, I can also calculate the variance of the percentage of currency held abroad. For my version of the DOLS estimator these standard errors are reasonably tight. If I used the other serial correlation correction, the standard errors are large and extend beyond the range of the sample. As a check I also estimated foreign holdings using one of the other methods, namely DGLS, which seemed to

\footnotetext{
${ }^{13}$ Figure 7 has 2 standard error bands on either side and has been smoothed with an HodrickPrescott filter $(\lambda=14400)$ for ease of reading.
} 
have different regression estimates. The numbers for this estimate were very similar to those obtained by my DOLS method, and the error bands were also quite tight. I also calculate the percentage foreign holdings by splitting the sample in two and estimating each of the subsamples. While there is a discrete jump at the break point, the overall numbers are reasonably similar in both the cases of the United States and Germany, and for the first half of Switzerland. The estimates for the United States are lower than those of Porter and Judson (1996) who estimated about 50-70 of the U.S. currency was held abroad over the entire period. For the pre-1980s period they are consistent with Seitz who estimated that about 30-40 percent of Germany's cash was abroad.

Furthermore "eyeballing" the estimates, there also seems to be some degree of persistence in the currency substitution, which is consistent with Kamin and Ericsson's (1993) hypothesis of hysteresis. Namely, agents switch to foreign currencies only after being subject to high inflation for some time, for example, and then take awhile to begin to trust the domestic currency again. The run-up in the United States for example that perhaps occurred because of instability in Latin America in the 70s and 80s did not fall back to its former level in percentage terms, though it did fall.

Why are my estimates different from those of the few studies that precede me? Porter and Judson (1996) report the U.S. in the 50-70 range for the period and Seitz (1995) lists Germany in the 30-40 percent range, whereas I have a 1996 estimate of $30 \%$ for the U.S. and $69 \%$ for Germany. My estimate for the United States is much closer to but still lower than that of Feige (1996) who using direct data on currency shipments comes up with about $40 \%$. One argument in favour of my numbers is that they look more reasonable. At 50-70\% the United States has a much lower level of currency per capita than many other industrialised nations in the world. In particular, it has a much lower number than Canada which it closely resembles. The opposite is true of Germany, with respect to the Netherlands. One possibility for the difference is that one of the assumption that Porter and Judson use, namely that foreign holdings have no seasonal component, is strongly violated in my results. If I run my series of holdings on seasonal dummies, most of them appear to be quite significant. This finding is not as surprising when matched with my anecdotal evidence, namely that the series match world events. This suggests that the holders are more likely to be Russian or Argentinian households than South American or South East Asian drug smugglers. It is also admittedly an artifact of the data, to the extent that the seasonality is not captured by the currency demand equation then it will be left in the foreign demand series. Finally, note that the degree of uncertainty is quite large so that we may not be able to truly ascertain what is the correct number. 


\subsubsection{Worldwide Currency Substitution}

The previous estimates of foreign holdings of currency may also have something to say about aggregate world currency substitution ${ }^{14}$. The United States, Germany, and Switzerland are likely to make up the vast majority of the world currencies held by citizens of other nations. Figure 8 shows the total U.S., German and Swiss currency held by foreigners in 1990 U.S. dollars. This amounted, in levels, to some 240 billion dollars U.S.. Again there have been two periods of increase. The first over the late 70 s and early 80 s and then again starting in the late 1980s. What is notable, as was in part apparent from the figures by percentages, is that by far the largest run-up in the size of currency substitution has occurred over that last decade. This potentially suggests that much of the run up in currency substitution has occurred because of the collapse of the former Soviet Union and the fall of the Iron Curtain. It is also been the case that the increase in the issuance of $\$ 100$ U.S. bills has increased over the same period.

Are these the only countries? One might think that there are several other countries that would fulfill this role most, notably Britain and France. The United Kingdom and France both have relatively low currency per capita levels suggesting that if they were to have sizable foreign holdings that they should also have little or no underground economy or much lower levels of currency use compared other industrialised nations. There may be a number of factors that contribute to their relative lack of use abroad. The best candidates for 'poundisation' and 'francisation' are the former colonies of these nations. Britain's colonies have either been relatively successful economies (South Africa, Australia, New Zealand, Canada, the Middle East, Hong Kong, Singapore, Malaysia) or rather poor ones (India, Africa). The Bank of England's notes also do not have the high denominations that America and Germany have $^{15}$. For France, many of her former colonies are in Africa and use the Central African Franc which was, for most of the period, pegged to the French franc. There

\footnotetext{
${ }^{14}$ The phenomenon of currency substitution or dollarisation is simply when households begin to use a currency or money of another nation usually because of monetary instability at home. Currency substitution is an ambiguous term that has come to mean one of two things: (1) that foreign currency has replaced all the functions preformed by the domestic money or (2) that a foreign currency has taken over the role as a medium of exchange. The first definition is associated with all forms of foreign money held by foreign agents. This tendency to hold a foreign currency may be particularly prevalent if there is sizable inflation in the country or if there is a large illegal or underground economy in the country. This latter is especially true if the underground is an 'export industry' such as the drug trade with links to the industrialised world. As we use it here, we only are referring to cash holdings, and understand the the problem of currency substitution extends beyond this definition.

${ }^{15}$ I thank Peter Kenen who also pointed out that during this period the British pound and the French franc fell in value and had higher inflation relative to Germany making them much less attractive to people wanting to hold another currency.
} 
are other countries that might have foreign holdings such as South Africa, India and Australia, but these are likely to be small. There is another currency that we might think has significant foreign holdings, in particular since it also has large per capita currency balances, namely Japan. I do not include it in this paper, because I have not been able to come up with a satisfactory proxy nation to do the analysis.

Most studies estimating the amount of currency substitution, have focused on a particular nation or set of nations. The number of studies trying to measure currency substitution is both its cash and bank deposit forms is quite large. There is a great difficulty in measuring the phenomena, precisely for the same reasons that it is hard to measure the whereabouts of the major world currencies. Most studies rely on some limited direct measures. Even they are difficult because those times where the phenomena is most interesting and harmful is usually during a period of crises, when data is harder to come by and, in the case of hyperinflation, sometimes suspect as it is difficult to know how to deflate variables. As I mentioned earlier in the paper, my calculations of world currency substitution can act as a benchmark for country estimates. The estimates are done 'from the other side' on industrialised nations with better data and who are likely to be more stable.

\section{Conclusions}

In this paper I have come up with better estimates of the international use of the US dollar, the German mark and the Swiss franc for currency substitution purposes. Previous estimates have been based on older time series techniques, whereas the estimates here have used more recent cointegration methods. These estimates are substantially different from the commonly accepted estimates. I have also found that currency substitution has risen dramatically over the past decade. This suggests that further work is needed to look at the destinations and effects of this outflow of cash. I have also looked at currency demand equations for a few nations. It is interesting that these functions with small denomination bills seem to have opposite signs and suggest further work on the determinants of currency demand.

These estimates might also be of help to answer other questions, not addressed in this paper. Can we get better estimates of currency substitution in individual countries, using information about the total? Certainly given data constraints, it may be wise to try to estimate currency substitution in a group of countries jointly using, for example, the world currency substitution estimates in this paper as a constraint. For the United States, Germany and Switzerland, having a time series of domestic and foreign held currency, we can try to look at where the domestic holdings of cash are - is it drug dealers, tax evaders or is it held in the legal economy, perhaps by those who prefer to hoard their savings in cash? Finally should countries in the world 
eliminate large denomination notes (see Rogoff (1998))? Or should a country care about the holdings of its currency abroad? If there was only one nation that had its currency held outside its country, it may be a question of the impact on illegal activities (both inside and outside the nation) versus the potential positive benefit that foreign agents get from having access to a stable currency, and the seignorage revenues that are reaped from those holdings. In that vein, what are the effects on crime or tax evasion of changes in the denomination of cash? If there are multiple currencies which could fill this role, then we add a strategic aspect. The withdrawal of one country's notes may just lead to the substitution of another's with no real benefit to be gained. All of these questions are potential areas for future research.

\section{References}

[1] Anderson, Paul S. (1977), "Currency in Use and in Hoards", New England Economic Review, Federal Reserve Bank of Boston, (March/April), 21-30.

[2] Avery, Robert B., Gregory E. Elliehausen, Arthur B. Kennickell, and Paul A. Spindt (1987), "Changes in the Use of Transaction Accounts and Cash from 1984 to 1986", Federal Reserve Bulletin, vol. 73 (March), 179-196.

[3] Ball, Laurence (1998), "Another Look at Long-run Money Demand," NBER Working Paper \#6597, June.

[4] Cramer, J. S., and G.M. Reekers (1976), "Money demand by sector: A survey for the Netherlands in 1971," Journal of Monetary Economics, vol. 2, 99-112.

[5] Feige, Edgar L. (1994), "The Underground Economy and the Currency Enigma," Public Finance/Finances Publiques, vol.49 (Special Issue), 119-136.

[6] Feige, Edgar L. (1996), "Where is America's Currency? Examining the World Dollarization Hypothesis", Midwest Economic Association Meetings, Chicago, Illinois, March 22, 1996, mimeo.

[7] Giovannini, Alberto and Bart Turtelboom (1994), "Currency Substitution," in Frederick van der Ploeg (ed.) The Handbook of International Macroeconomics, Basil Blackwell, Oxford, United Kingdom.

[8] Goldfeld, Stephen M., and D.E. Sichel (1990), "The Demand for Money," in B.M. Friedman and F.H. Hahn (eds), The Handbook of Monetary Economics, Volume 1, Elsevier Science Publishers, Amsterdam, 300-356. 
[9] Haag, A.A. and R. F. Lucas (1996), "Long-run Money Demand in Canada: In search of stability," Review of Economics and Statistics, vol. 78, 2, 345-348.

[10] Hamilton, James D. (1994), "Time Series Analysis," Princeton University Press, Princeton, NJ.

[11] Hansen, Bruce (1992), "Tests for Parameter Instability in Regressions with I(1) Processes," Journal of Business and Economic Statistics, vol. 10, 3 (July), 321335.

[12] Haughton, Jonathan (1995), "Adding Mystery to the Case of the Missing Currency," Quarterly Review of Economics and Finance, vol. 35, (Special Issue), 595-602.

[13] Kamin, Steven B., and Neil R. Ericsson (1993), "Dollarization in Argentina," International Finance Discussion Papers no. 460, Board of Governors of the Federal Reserve System.

[14] Porter, Richard D. and Ruth A. Judson (1996), "The Location of U.S. Currency: How Much is Abroad?", Board of Governors of the Federal Reserve System, Washington, mimeo, April 15.

[15] Rogoff, Kenneth S. (1998), "Foreign and Underground Demand for Euro Notes: Blessing or Curse?," Economic Policy, 26: April, 263-303.

[16] Savastano, Miguel A. (1996), "Dollarization in Latin America: recent evidence and policy issues", in Paul Mizen and Eric J. Pentecost, The Macroeconomics of International Currencies: Theory, Policy and Evidence, Edward Elgar, Cheltenham, U.K.

[17] Seitz, Franz (1995), "The Circulation of Deutsche Mark Abroad", Discussion Paper 1/95, Economic Research Group of the Deutsche Bundesbank, (May).

[18] Sprenkle, Case M. (1993), "The Case of the Missing Currency," Journal of Economic Perspectives, vol. 7, 4 (Fall), 175-184.

[19] Stock, James, and Mark Watson (1993), "A Simple Estimator of Cointegrating Vectors in Higher Order Integrated Systems," Econometrica, 64, 4(July), 783820.

[20] Sumner, Scott B. (1990), "The Transactions and Hoarding Demand for Currency", Quarterly Review of Economics and Business, vol. 30, 1 (Spring), 75-89. 


\section{Tables and Graphs}

Table 1: Currency Stocks in Selected Countries

\begin{tabular}{cccc}
\hline \hline Country & $\begin{array}{c}\text { Currency } \\
\text { (billions of dollars) }\end{array}$ & $\begin{array}{c}\text { Population } \\
\text { (millions) }\end{array}$ & $\begin{array}{c}\text { Per capita currency } \\
\text { (dollars) }\end{array}$ \\
\hline Argentina & 11.16 & 34.77 & 380.82 \\
Austria & 14.11 & 8.53 & 1659.48 \\
Brazil & 13.64 & 155.82 & 87.51 \\
Canada & 21.46 & 29.61 & 724.71 \\
Czech Republic & 3.93 & 10.33 & 380.31 \\
Denmark & 5.46 & 5.23 & 276.1 \\
France & 51.69 & 58.03 & 890.71 \\
Germany & 165.72 & 81.64 & 2029.94 \\
Hungary & 3.91 & 10.26 & 380.65 \\
Iceland & 0.08 & 0.27 & 292.61 \\
India & 35.04 & 935.74 & 37.44 \\
Ireland & 2.87 & 3.58 & 800.46 \\
Italy & 60.34 & 57.19 & 1055.00 \\
Japan & 491.49 & 124.96 & 3933.22 \\
Mexico & 9.48 & 90.49 & 104.73 \\
Netherlands & 23.78 & 15.45 & 1539.42 \\
New Zealand & .65 & 3.54 & 276.10 \\
Poland & 8.05 & 38.59 & 208.70 \\
Russia & 17.71 & 148.14 & 119.66 \\
Saudi Arabia & 11.51 & 7.45 & 659.37 \\
Singapore & 6.99 & 2.99 & 2337.97 \\
Slovenia & 0.51 & 1.99 & 254.22 \\
South Africa & 51.98 & 41.24 & 1260.34 \\
Switzerland & 27.92 & 7.04 & 3966.46 \\
Thailand & 11.40 & 60.21 & 189.38 \\
United Kingdom & 33.48 & 58.26 & 574.67 \\
United States & 382.1 & 263.03 & 1452.69 \\
\hline \hline
\end{tabular}

Source: International Monetary Fund, International Financial Statistics, February 1997 (for year 1995). 
Table 2: United States Household Surveys on Currency Holdings

\begin{tabular}{|c|c|c|c|}
\hline Percentage of currency stock & June 1984 & June 1986 & May 1995 \\
\hline Household Transactions & 15.6 & 15.3 & 7.2 \\
\hline Household Hoards & 2.0 & 1.9 & 1.2 \\
\hline
\end{tabular}

Table 3: Comparison of the Relative Importance of Payment Instruments Other Than Cash as a percentage of cashless transactions

\begin{tabular}{lc|lllll}
\hline \hline Countries & Year & Cheques & $\begin{array}{l}\text { Credit } \\
\text { Card } \\
\text { Payments }\end{array}$ & $\begin{array}{l}\text { Debit Card } \\
\text { Payments } \\
\text { at POS }\end{array}$ & $\begin{array}{l}\text { Paperless and } \\
\text { Paper-based } \\
\text { Credit } \\
\text { Transactions }\end{array}$ & $\begin{array}{l}\text { Direct } \\
\text { Debits }\end{array}$ \\
\hline Canada & 1983 & 91.0 & 7.0 & - & Insignificant & 2 \\
& 1987 & 72.40 & 23.50 & 0.00 & 2.60 & 1.50 \\
United States & 1991 & 64.8 & 27.8 & - & 3.9 & 3.5 \\
& 1995 & 46.9 & 40.0 & - & 7.4 & 5.8 \\
& 1983 & 98.6 & 7.2 & - & 0.9 & $<1$ \\
Netherlands & 1997 & 82.90 & 15.30 & 0.10 & 1.1 & 0.50 \\
& 1995 & 76.6 & 16.0 & - & 1.6 & 0.8 \\
& 1983 & 22.3 & 20.1 & - & 2.3 & 1.2 \\
& 1987 & 19.00 & $<0.50$ & $<0.50$ & 64.50 & 16.50 \\
Germany & 1991 & 14.3 & 1.8 & - & 61.3 & 22.6 \\
& 1995 & 5.9 & 11.3 & - & 56.6 & 26.3 \\
& 1983 & 11.0 & Insignificant & - & 32.0 & 57.0 \\
& 1987 & 8.60 & 0.60 & 0.00 & 54.80 & 36.00 \\
& 1991 & 9.6 & 1.8 & - & 51.3 & 37.3 \\
& 1995 & 7.0 & 3.6 & - & 48.8 & 40.6 \\
Switzerland & 1983 & 10.6 & 0.5 & - & 0.8 & 88.0 \\
& 1987 & 13.80 & 3.00 & 0.30 & 79.90 & 3.00 \\
& 1991 & 5.4 & 9.7 & - & 80.1 & 2.8 \\
& 1995 & 2.0 & 18.4 & - & 76.3 & 3.3 \\
\hline \hline
\end{tabular}

From the BIS, "Payment Systems in Eleven Developed Countries." 
Table 4: Currency Demand Cointegrating Vectors: Estimates and Tests, Monthly Data (standard errors in brackets)

\begin{tabular}{|c|c|c|c|c|c|c|}
\hline \multicolumn{7}{|c|}{$\begin{array}{l}\text { Dynamic OLS/GLS estimation equation: } \\
\left.\text { (Real Currency Balances })=\beta_{0}+\beta_{1} \text { (Retail Sales }\right)+\beta_{2} \text { (Interest Rate) } \\
\left.\left.+d_{R S}(L) \text { (Retail Sales }\right)+d_{I}(L) \text { (Interest Rate }\right)+e_{t}\end{array}$} \\
\hline & \multicolumn{2}{|c|}{ Canada } & \multicolumn{2}{|c|}{ Netherlands } & \multicolumn{2}{|c|}{ Austria } \\
\hline Estimator & $\beta_{1}$ & $\beta_{2}$ & $\beta_{1}$ & $\beta_{2}$ & $\beta_{1}$ & $\beta_{2}$ \\
\hline SOLS & 0.586 & -0.27 & -0.15 & 0.710 & 0.363 & -0.24 \\
\hline NLLS & 1.164 & 11.96 & -1.58 & 0.228 & 1.170 & -2.24 \\
\hline DOLS & $\begin{array}{l}0.917 \\
(0.084)\end{array}$ & $\begin{array}{l}-1.17 \\
(0.348)\end{array}$ & $\begin{array}{l}-0.32 \\
(0.107)\end{array}$ & $\begin{array}{l}1.153 \\
(0.460)\end{array}$ & $\begin{array}{l}0.537 \\
(0.034)\end{array}$ & $\begin{array}{l}-0.84 \\
(0.427)\end{array}$ \\
\hline DGLS & $\begin{array}{l}0.280 \\
(0.035)\end{array}$ & $\begin{array}{l}-0.32 \\
(0.201)\end{array}$ & $\begin{array}{l}0.135 \\
(0.052)\end{array}$ & $\begin{array}{l}-0.37 \\
(0.155)\end{array}$ & $\begin{array}{l}0.032 \\
(0.036)\end{array}$ & $\begin{array}{l}-0.57 \\
(0.768)\end{array}$ \\
\hline PBSR & $\begin{array}{l}0.891 \\
(0.093)\end{array}$ & $\begin{array}{l}-1.07 \\
(0.386)\end{array}$ & $\begin{array}{l}-0.32 \\
(0.106)\end{array}$ & $\begin{array}{l}1.084 \\
(0.444)\end{array}$ & $\begin{array}{l}0.525 \\
(0.042)\end{array}$ & $\begin{array}{l}-0.76 \\
(0.538)\end{array}$ \\
\hline PHFM & $\begin{array}{l}0.777 \\
(0.066)\end{array}$ & $\begin{array}{l}-0.76 \\
(0.329)\end{array}$ & $\begin{array}{l}-0.26 \\
(0.084)\end{array}$ & $\begin{array}{l}1.020 \\
(0.399)\end{array}$ & $\begin{array}{l}0.477 \\
(0.030)\end{array}$ & $\begin{array}{l}-0.60 \\
(0.478)\end{array}$ \\
\hline $\mathrm{JOH}(2)$ & $\begin{array}{l}1.791 \\
(0.233)\end{array}$ & $\begin{array}{l}-4.05 \\
(0.865)\end{array}$ & $\begin{array}{l}-2.54 \\
(1.040)\end{array}$ & $\begin{array}{l}4.701 \\
(2.312)\end{array}$ & $\begin{array}{l}0.771 \\
(0.047)\end{array}$ & $\begin{array}{l}-1.45 \\
(0.499)\end{array}$ \\
\hline \multirow[t]{2}{*}{$\mathrm{JOH}(3)$} & $\begin{array}{l}1.876 \\
(0.340)\end{array}$ & $\begin{array}{l}-5.13 \\
(1.416)\end{array}$ & $\begin{array}{l}-2.29 \\
(0.904)\end{array}$ & $\begin{array}{l}2.793 \\
(1.823)\end{array}$ & $\begin{array}{l}0.708 \\
(0.046) \\
\end{array}$ & $\begin{array}{l}-1.31 \\
(0.531)\end{array}$ \\
\hline & \multicolumn{2}{|c|}{ United States } & \multicolumn{2}{|c|}{ Germany } & \multicolumn{2}{|c|}{ Switzerland } \\
\hline Estimator & $\beta_{1}$ & $\beta_{2}$ & $\beta_{1}$ & $\beta_{2}$ & $\beta_{1}$ & $\beta_{2}$ \\
\hline SOLS & 0.787 & -1.49 & 0.693 & 0.493 & 0.415 & -1.33 \\
\hline NLLS & 1.227 & 0.796 & 2.511 & 12.28 & 1.848 & 3.269 \\
\hline DOLS & $\begin{array}{l}1.143 \\
(0.072)\end{array}$ & $\begin{array}{l}-1.94 \\
(0.257)\end{array}$ & $\begin{array}{l}1.021 \\
(0.147)\end{array}$ & $\begin{array}{l}-0.30 \\
(0.960)\end{array}$ & $\begin{array}{l}0.750 \\
(0.075)\end{array}$ & $\begin{array}{l}-1.65 \\
(0.436)\end{array}$ \\
\hline DGLS & $\begin{array}{l}0.253 \\
(0.042)\end{array}$ & $\begin{array}{l}-0.46 \\
(0.197)\end{array}$ & $\begin{array}{l}0.025 \\
(0.038)\end{array}$ & $\begin{array}{l}-0.35 \\
(0.281)\end{array}$ & $\begin{array}{l}0.157 \\
(0.021)\end{array}$ & $\begin{array}{l}-0.60 \\
(0.446)\end{array}$ \\
\hline PBSR & $\begin{array}{l}1.130 \\
(0.084)\end{array}$ & $\begin{array}{l}-1.88 \\
(0.295)\end{array}$ & $\begin{array}{l}1.007 \\
(0.149)\end{array}$ & $\begin{array}{l}-0.19 \\
(0.971)\end{array}$ & $\begin{array}{l}0.674 \\
(0.083)\end{array}$ & $\begin{array}{l}-1.63 \\
(0.518)\end{array}$ \\
\hline PHFM & $\begin{array}{l}1.038 \\
(0.067)\end{array}$ & $\begin{array}{l}-1.81 \\
(0.279)\end{array}$ & $\begin{array}{l}0.925 \\
(0.121)\end{array}$ & $\begin{array}{l}0.017 \\
(0.897)\end{array}$ & $\begin{array}{l}0.554 \\
(0.051)\end{array}$ & $\begin{array}{l}-1.55 \\
(0.484)\end{array}$ \\
\hline $\mathrm{JOH}(2)$ & $\begin{array}{l}1.627 \\
(0.138)\end{array}$ & $\begin{array}{l}-2.55 \\
(0.404)\end{array}$ & $\begin{array}{l}3.118 \\
(0.788)\end{array}$ & $\begin{array}{l}-5.22 \\
(3.192)\end{array}$ & $\begin{array}{l}1.576 \\
(0.191)\end{array}$ & $\begin{array}{l}-2.06 \\
(0.758)\end{array}$ \\
\hline $\mathrm{JOH}(3)$ & $\begin{array}{l}1.598 \\
(0.167)\end{array}$ & $\begin{array}{l}-2.51 \\
(0.504)\end{array}$ & $\begin{array}{l}3.430 \\
(1.174)\end{array}$ & $\begin{array}{l}-8.66 \\
(5.256)\end{array}$ & $\begin{array}{l}1.625 \\
(0.221)\end{array}$ & $\begin{array}{l}-1.89 \\
(0.859)\end{array}$ \\
\hline
\end{tabular}


Table 5: Currency Demand Cointegrating Vectors: Estimates and Tests, Large Denomination Bills (standard errors in brackets)

\begin{tabular}{lllllll}
\hline \hline & Canada & \multicolumn{3}{c}{ Netherlands } & Austria \\
Estimator & $\beta_{1}$ & $\beta_{2}$ & $\beta_{1}$ & $\beta_{2}$ & $\beta_{1}$ & $\beta_{2}$ \\
\hline SOLS & 1.774 & -0.00 & 0.087 & 1.560 & 0.972 & -0.16 \\
NLLS & 3.242 & -1.55 & -3.56 & -2.69 & 2.025 & -2.99 \\
DOLS & 3.235 & -3.79 & 0.057 & 1.942 & 1.551 & -2.11 \\
& $(0.206)$ & $(0.857)$ & $(0.176)$ & $(0.756)$ & $(0.061)$ & $(0.780)$ \\
DGLS & 0.203 & -0.20 & 0.161 & -0.43 & 0.225 & -0.64 \\
& $(0.024)$ & $(0.150)$ & $(0.057)$ & $(0.177)$ & $(0.031)$ & $(0.688)$ \\
PBSR & 3.156 & -3.49 & 0.052 & 1.834 & 1.511 & -1.91 \\
& $(0.264)$ & $(1.091)$ & $(0.173)$ & $(0.722)$ & $(0.096)$ & $(1.220)$ \\
PHFM & 2.630 & -2.08 & 0.066 & 1.902 & 1.341 & -1.30 \\
& $(0.194)$ & $(0.963)$ & $(0.136)$ & $(0.647)$ & $(0.071)$ & $(1.112)$ \\
JOH(2) & 4.692 & -8.01 & -17.5 & -3.63 & 1.935 & -3.05 \\
& $(0.364)$ & $(1.354)$ & $(39.52)$ & $(19.10)$ & $(0.070)$ & $(0.762)$ \\
JOH $(3)$ & 4.644 & -7.88 & -8.53 & -4.37 & 1.964 & -3.32 \\
& $(0.392)$ & $(1.473)$ & $(9.900)$ & $(10.42)$ & $(0.088)$ & $(0.959)$ \\
\hline
\end{tabular}

Table 6: Currency Demand Cointegrating Vectors: Estimates and Tests, Small Denomination Bills (standard errors in brackets)

\begin{tabular}{lllllll}
\hline \hline & Canada & \multicolumn{3}{c}{ Netherlands } & Austria \\
Estimator & $\beta_{1}$ & $\beta_{2}$ & $\beta_{1}$ & $\beta_{2}$ & $\beta_{1}$ & $\beta_{2}$ \\
\hline SOLS & 0.021 & 0.390 & -0.64 & -2.51 & -0.73 & 1.078 \\
NLLS & -2.27 & -5.37 & -3.12 & 1.330 & -1.44 & 3.557 \\
DOLS & -0.18 & 0.903 & -1.08 & -2.29 & -1.29 & 3.040 \\
& $(0.106)$ & $(0.439)$ & $(0.248)$ & $(1.065)$ & $(0.055)$ & $(0.703)$ \\
DGLS & 0.318 & -0.24 & 0.073 & -0.30 & -0.06 & 0.060 \\
& $(0.045)$ & $(0.259)$ & $(0.053)$ & $(0.156)$ & $(0.055)$ & $(1.378)$ \\
PBSR & -0.16 & 0.839 & -1.07 & -2.19 & -1.26 & 2.925 \\
& $(0.105)$ & $(0.436)$ & $(0.249)$ & $(1.038)$ & $(0.082)$ & $(1.044)$ \\
PHFM & -0.10 & 0.690 & -0.93 & -2.57 & -1.08 & 2.262 \\
& $(0.078)$ & $(0.390)$ & $(0.196)$ & $(0.933)$ & $(0.066)$ & $(1.038)$ \\
JOH(2) & -1.85 & 6.144 & -4.17 & 2.412 & -1.51 & 3.832 \\
& $(0.663)$ & $(2.262)$ & $(0.957)$ & $(2.581)$ & $(0.069)$ & $(0.812)$ \\
JOH(3) & -1.68 & 5.389 & -4.33 & 4.922 & -1.50 & 3.906 \\
& $(0.699)$ & $(2.352)$ & $(1.074)$ & $(3.235)$ & $(0.058)$ & $(0.699)$ \\
\hline
\end{tabular}



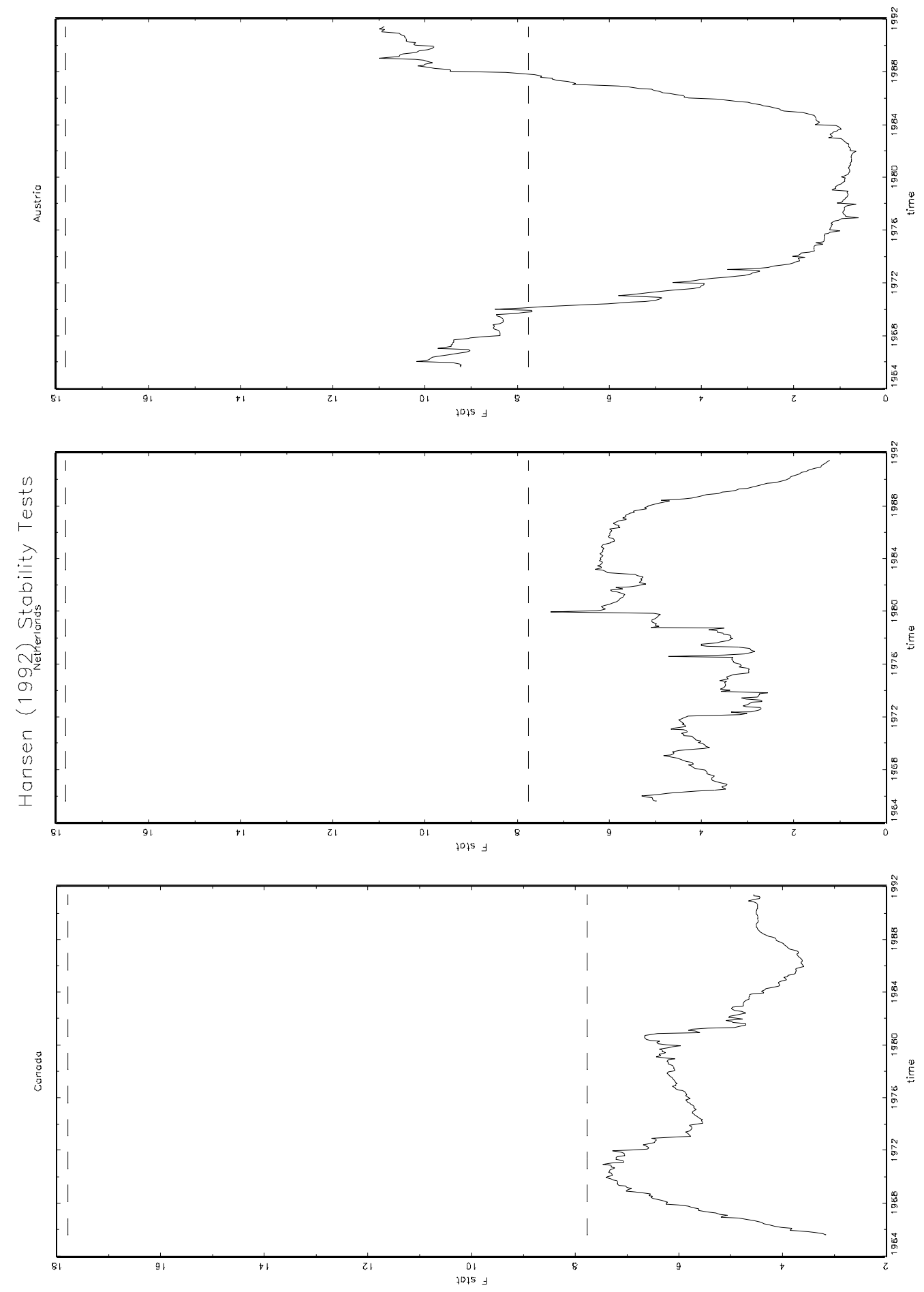

Figure 1: Hansen (1992) Stability Tests (upper line is the 5\% SupF critical value, lower line is the $5 \%$ MeanF critical value) 

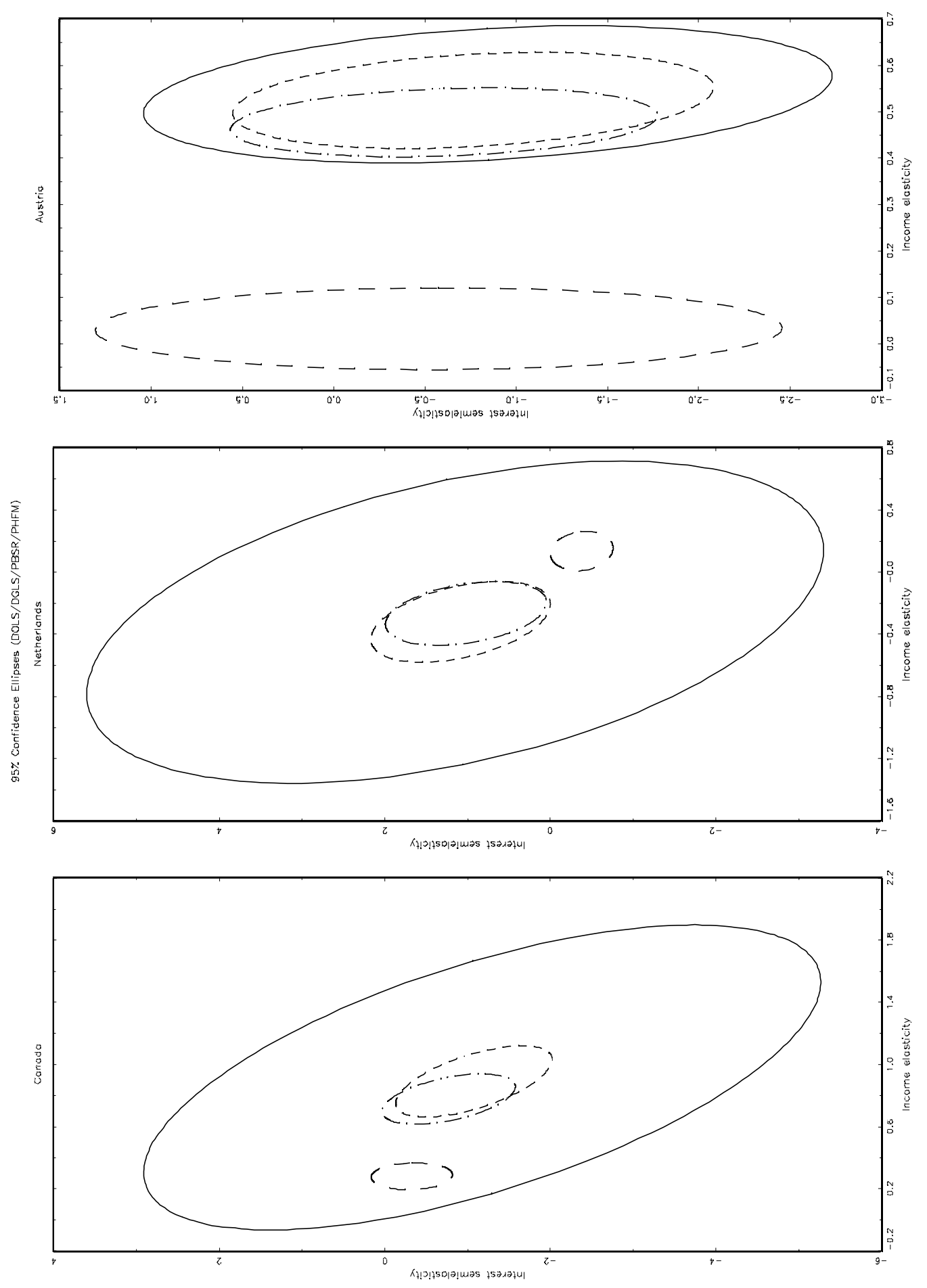

Figure 2: 95\% Confidence Ellipses (DOLS - line, DGLS - dashes, PBSR - short dashes, PHFM - dash-dots) 

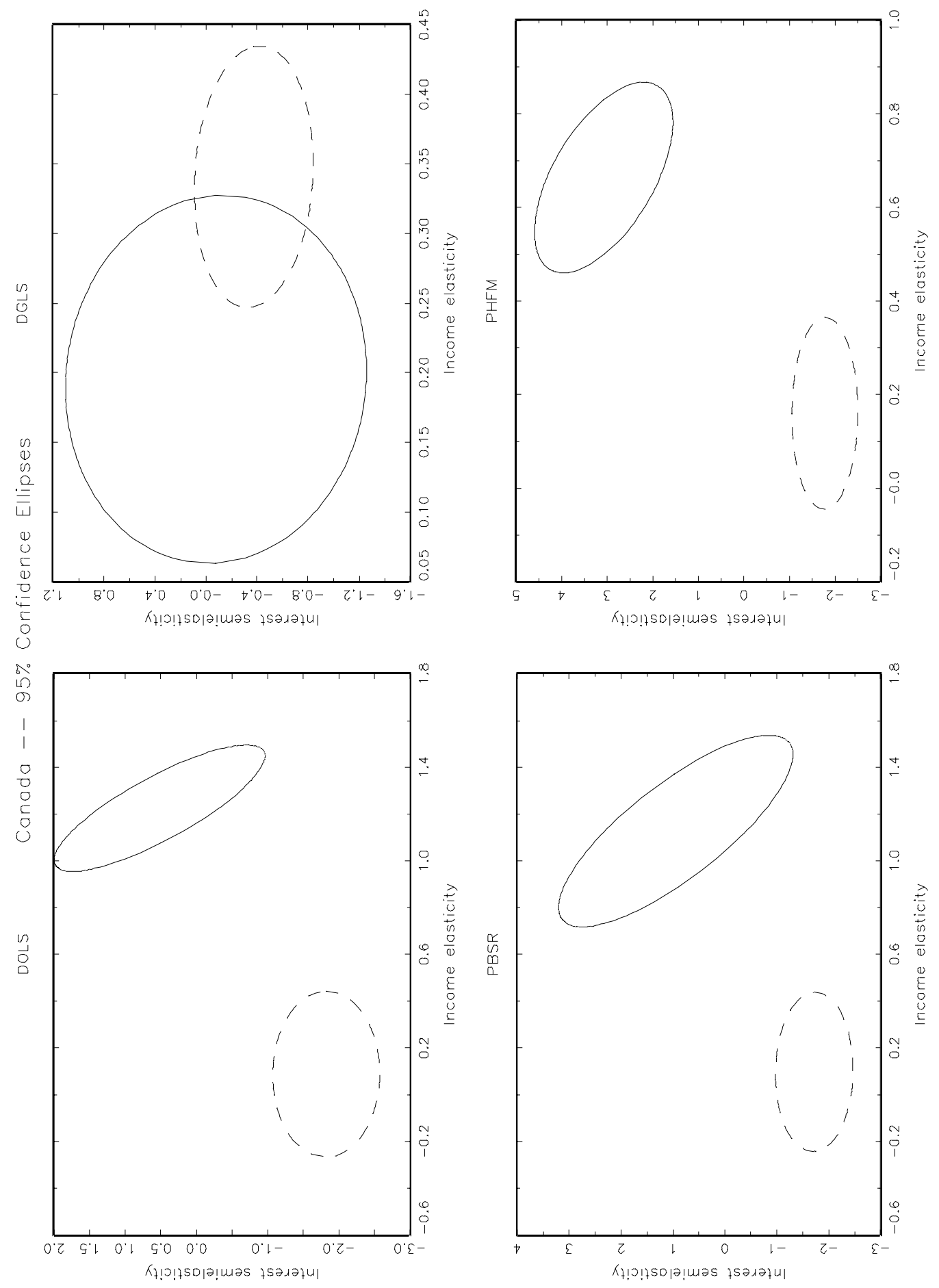

Figure 3: 95\% Confidence Ellipses for Canada (line is the first half of the sample, dotted line is the second half) 

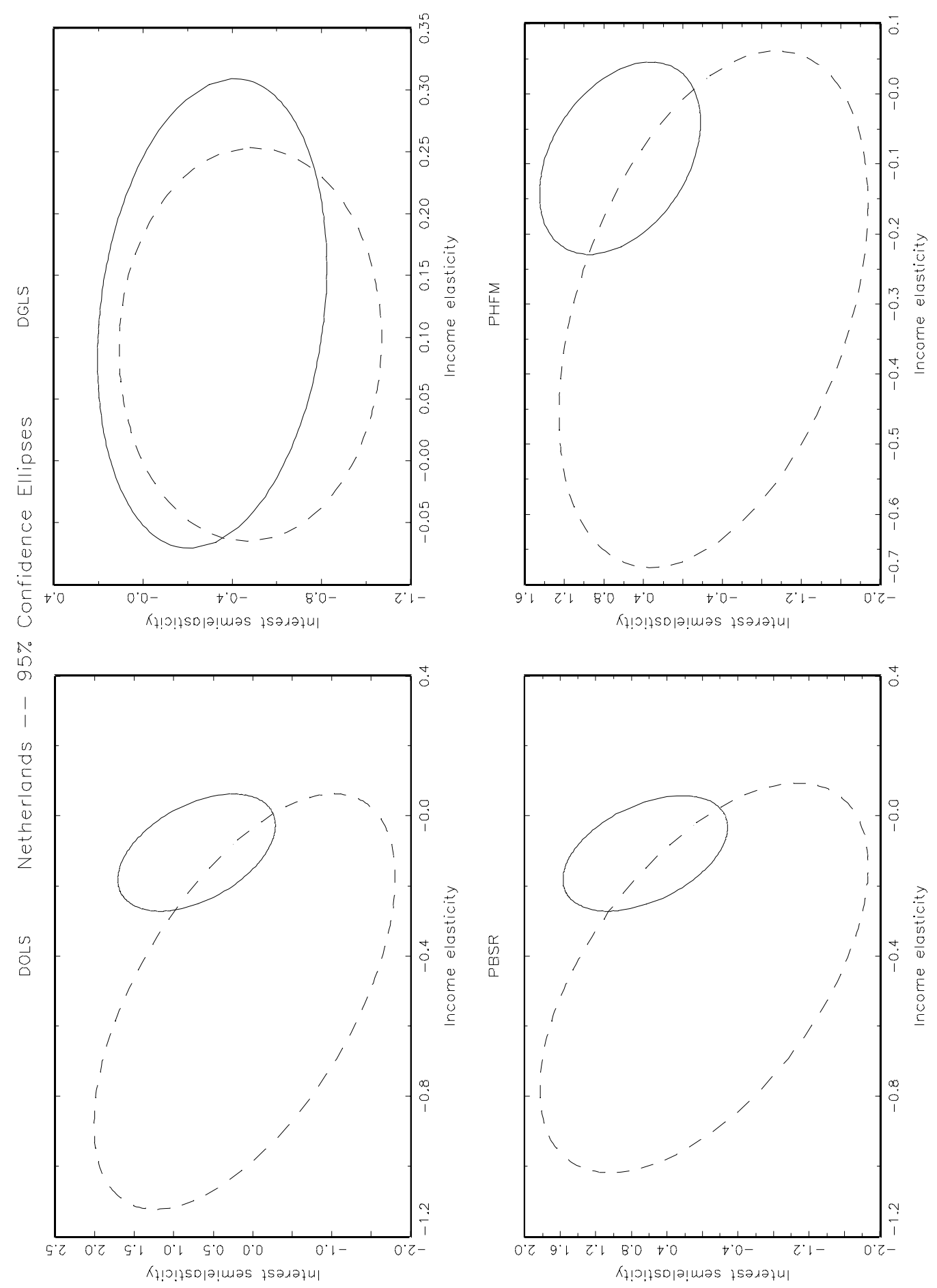

Figure 4: 95\% Confidence Ellipses for the Netherlands (line is first half of sample, dotted line is the second half.) 

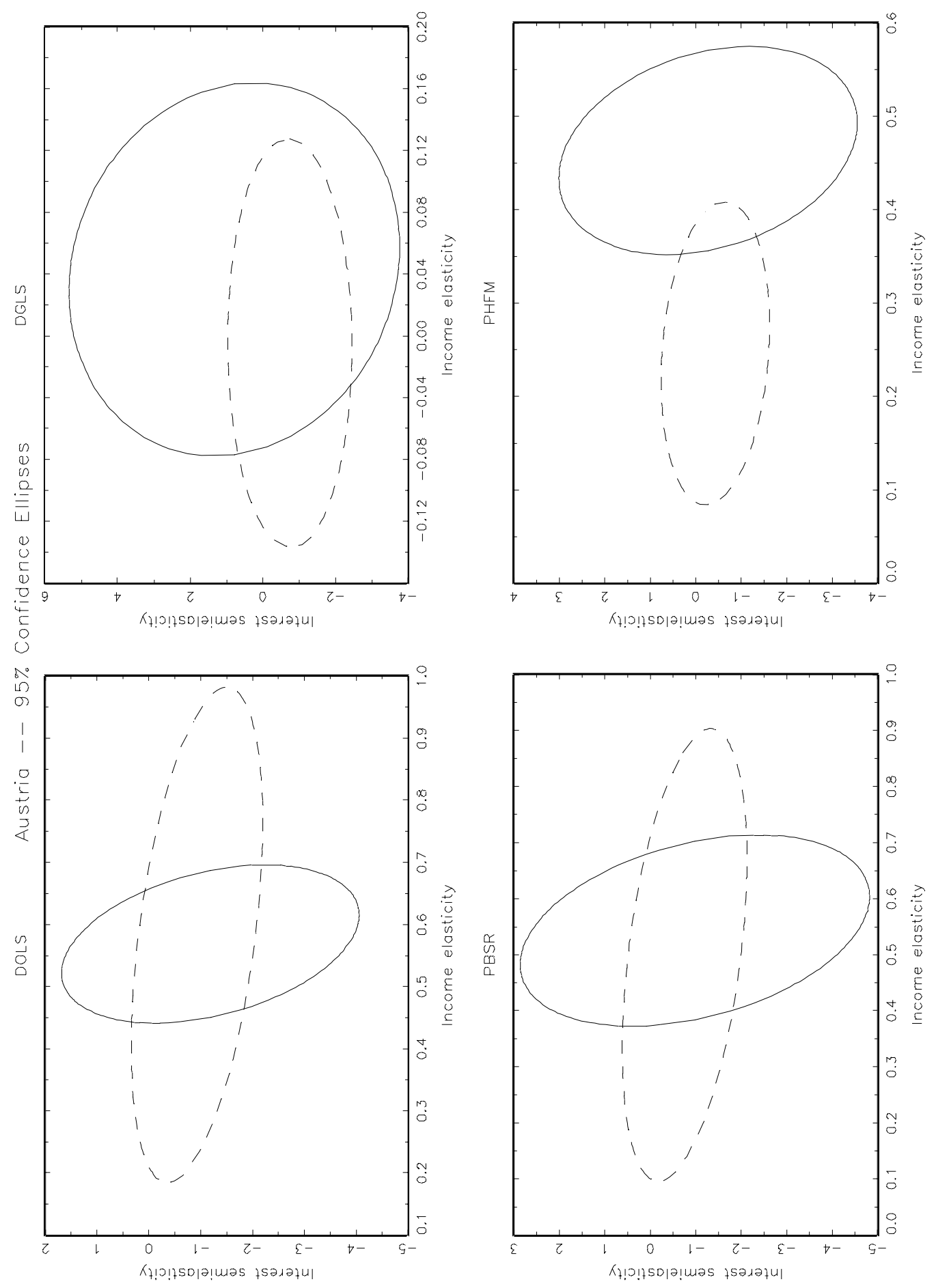

Figure 5: 95\% Confidence Ellipses for Austria (line is first half of sample, dotted line is the second half.) 

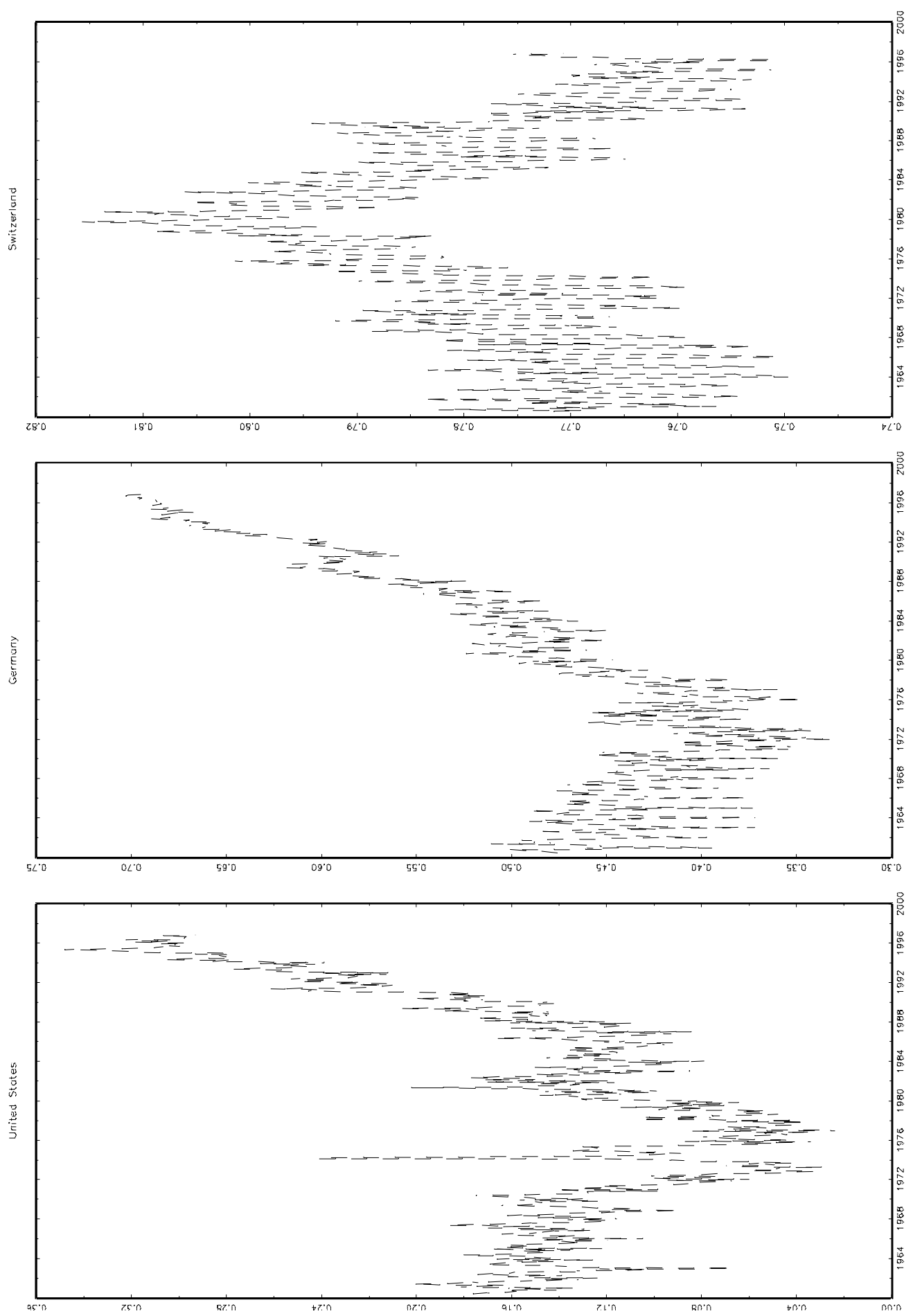

Figure 6: Foreign Holdings as a Percentage of the Currency Stock (DOLS) 

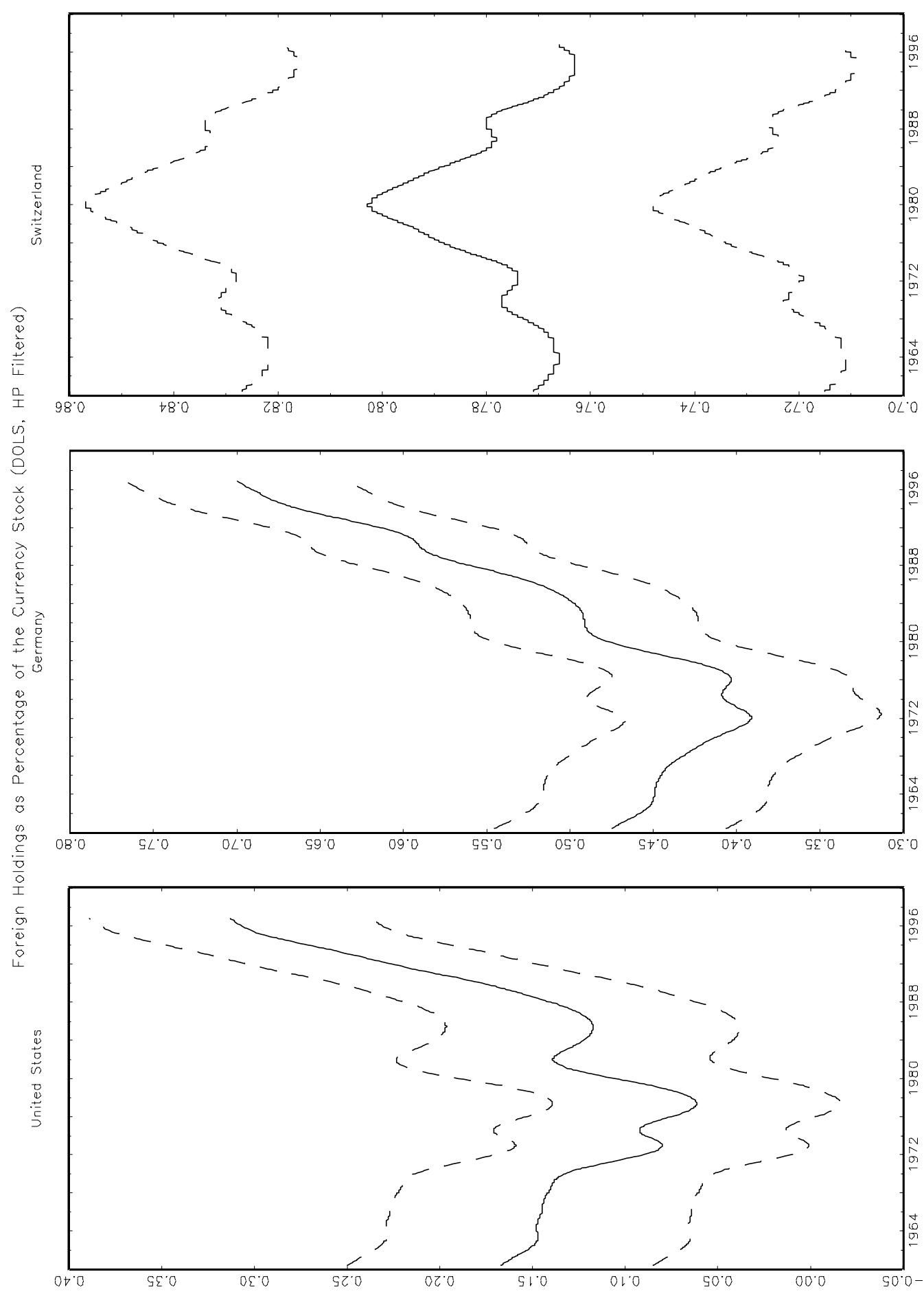

Figure 7: Foreign Holdings as a Percentage of the Currency Stock (DOLS) [with 2 standard error bands] 
World Dollarization (DOLS)

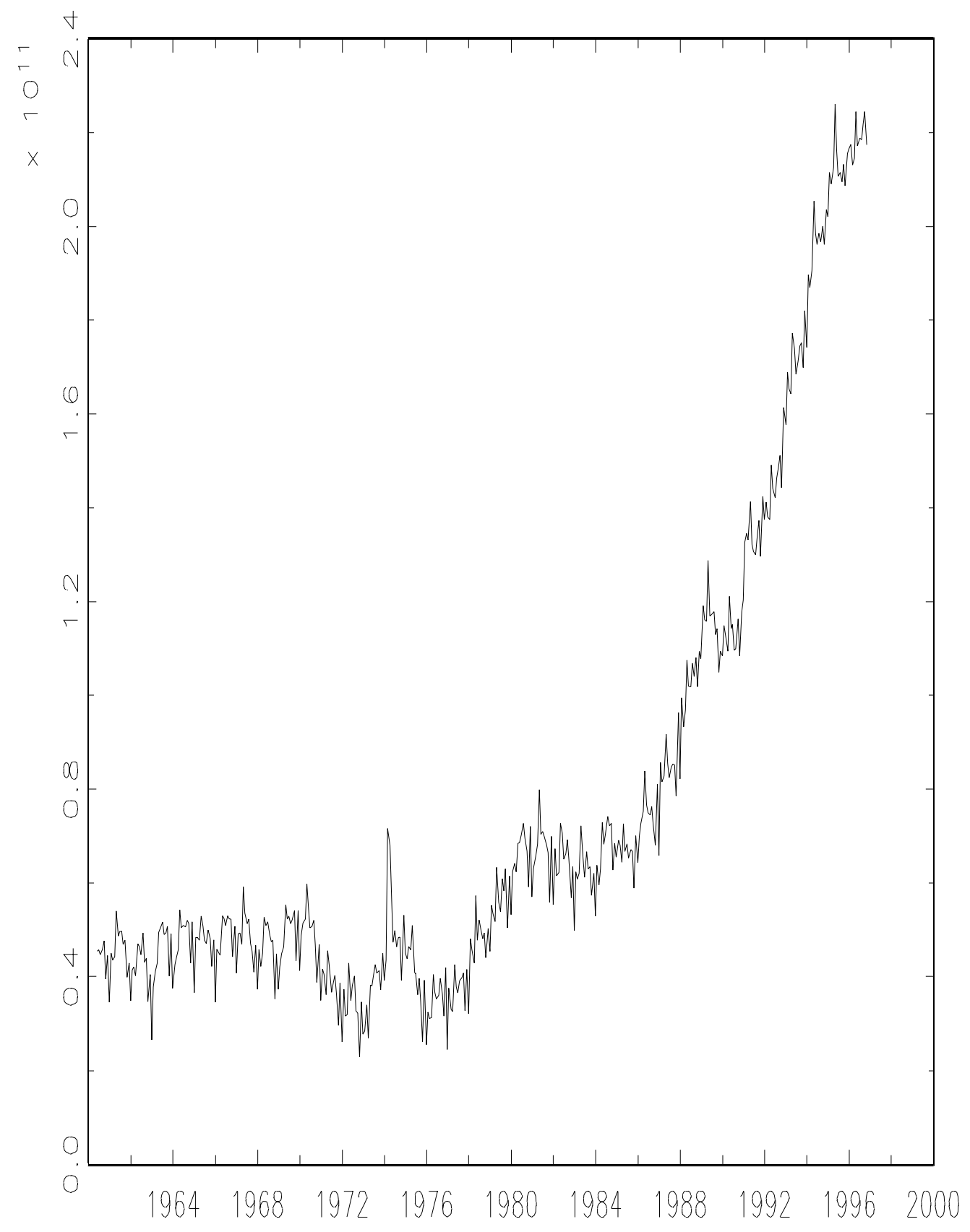

Figure 8: World Dollarization (in 1990 U.S. Dollars - DOLS) 